\title{
Guanine nucleotide binding protein involved in muscarinic responses in the pig coronary artery is insensitive to islet-activating protein
}

\author{
Toshiyuki SASAGURI,* Masato HIRATA, $\dagger$ Takeo ITOH,* Toshitaka KOGA $\dagger$ and Hirosi KURIYAMA* \\ $\dagger$ Department of Biochemistry, Faculty of Dentistry, and *Department of Pharmacology, Faculty of Medicine, Kyushu \\ University, Fukuoka 812, Japan
}

In an attempt to identify the nature of guanine nucleotide binding protein(s) (G-protein) involved in the acetylcholine ( $\mathrm{ACh}$ )-induced (muscarinic) response of pig coronary-artery smooth muscle, we studied the effect of ADP-ribosylation of specific membrane protein(s) catalysed by islet-activating protein (IAP; pertussis toxin). The ACh-stimulated and guanine nucleotide-dependent activities of phosphatidylinositol 4,5-bisphosphate $\left(\mathrm{PIP}_{2}\right.$ ) phosphodiesterase (PDE), assessed by the production of inositol 1,4,5trisphosphate $\left(\mathrm{IP}_{3}\right)$ from exogenously applied $\mathrm{PIP}_{2}$, were not modified, in either IAP-treated or non-treated cell homogenates used as the enzyme source. In intact tissues, pretreatment with up to $100 \mathrm{ng}$ of IAP/ml inhibited neither the ACh-induced decrease in the amount of inositol phospholipids nor the increase in the amounts of phosphatidic acid and of inositol phosphates. IAP treatment increased the amount of cyclic AMP accumulated by isoprenaline. These observations suggest that G-protein which couples the muscarinic receptor to PIP $_{2}-\mathrm{PDE}$ is insensitive to IAP. Such being the case, the nature of this protein(s) probably differs from that required for the regulation of adenylate cyclase activities $\left(N_{i}\right.$ or $\left.G_{i}\right)$.

\section{INTRODUCTION}

The agonist-induced stimulation of phosphatidylinositol 4,5-bisphosphate $\left(\mathrm{PIP}_{2}\right)$ hydrolysis has been given increasing attention, as two types of second messengers, inositol 1,4,5-trisphosphate $\left(\mathrm{IP}_{3}\right)$ and diacylglycerol, are produced by hydrolysis (Berridge \& Irvine, 1984; Nishizuka, 1984). In contrast with studies on the function of $\mathrm{IP}_{3}$ or protein kinase $\mathrm{C}$ through diacylglycerol, little is known of mechanisms by which receptor occupation induces the hydrolysis of PIP P $_{2}$ Reports on work with mast cells (Gomperts, 1983), platelets (Haslam \& Davidson, 1984), neutrophils (Cockcroft \& Gomperts, 1985), salivary glands (Litosch et al., 1985) or hepatocytes (Wallace \& Fain, 1985) indicated that a guanine nucleotide binding protein(s) (G-protein) is involved in coupling specific receptors to the phosphodiesterase (PDE or phospholipase C) causing PIP $_{2}$ hydrolysis. This suggestion was based on observations that, in membrane preparations or permeabilized cells, GTP and its unhydrolysable analogues (but not GDP and its analogues, which competitively inhibit the GTP-evoked effects) stimulated the PIP $_{2}$ hydrolysis and elicited specific functions, for example 5-hydroxytryptamine (serotonin) secretion in platelets (Haslam \& Davidson, 1984).

Nakamura \& Ui (1985) reported that treatment of rat peritoneal mast cells with islet-activating protein (IAP; pertussis toxin) for $2 \mathrm{~h}$ blocked $\mathrm{PIP}_{2}$ hydrolysis and histamine secretion, as induced by compound $48 / 80$. These inhibitory effects induced by IAP correlated well with the IAP-catalysed ADP-ribosylation of the $41 \mathrm{kDa}$ protein, which may be the same as, or closely related to, the $\alpha$ subunit of $\mathrm{N}_{\mathrm{i}}$ (or $\mathrm{G}_{\mathrm{i}}$ ), the inhibitory G-protein of the adenylate cyclase system (Ui, 1984), as shown by its $M_{\mathrm{r}}$ and inhibition of ADP-ribosylation in the presence of guanosine 5 - $[\gamma$-thio $]$ triphosphate (GTP[S]). Essentially the same observations were made with neutrophils stimulated with chemotactic peptides by Ui's group (Okajima et al., 1985) and others (Smith et al., 1985). Therefore they concluded that the G-protein involved in the receptor-stimulated PIP $_{2}$ hydrolysis is the IAP substrate $\mathbf{N}_{\mathbf{i}}$, at least in mast cells and neutrophils.

In a previous study (Sasaguri et al., 1985), we suggested that a G-protein is involved in the muscarinic

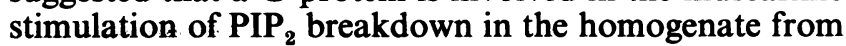
the pig coronary-arterial smooth muscle. The purpose of the present study was to clarify the nature of this G-protein. For this purpose, we examined the effect of IAP treatment on $\mathrm{PIP}_{2}-\mathrm{PDE}$ activity, using the cell homogenate as the enzyme source and exogenous ${ }^{32} \mathrm{P}$-labelled $\mathrm{PIP}_{2}$ as the substrate. In addition, in intact cells, ACh-induced hydrolysis of inositol phospholipids, accumulation of inositol phosphates, and mechanical responses were also examined, in both control (nontreated) and IAP-treated muscle tissues.

\section{MATERIALS AND METHODS}

\section{Preparation of cell homogenate and ADP-ribosylation by IAP}

Coronary arteries were excised from pig hearts obtained at a local abattoir within $30 \mathrm{~min}$ after slaughter. Adventitia and adherent connective tissue were carefully removed under a binocular microscope,

\footnotetext{
Abbreviations used: PIP $_{2}$, phosphatidylinositol 4,5-bisphosphate; PIP, phosphatidylinositol 4-phosphate; PI, phosphatidylinositol; PA, phosphatidic acid; $\mathrm{IP}_{3}$, inositol 1,4,5-trisphosphate; $\mathrm{IP}_{2}$, inositol 1,4-bisphosphate; IP, inositol monophosphate; PDE, phosphodiesterase; G-protein, guanine nucleotide binding protein; IAP, islet-activating protein; GTP[S], guanosine $5^{\prime}-[\gamma$-thio]triphosphate; ACh, acetylcholine.
}

Vol. 239 
and the endothelium was carefully ablated with cottonwool.

Muscle strips (about $1.5 \mathrm{~g}$ wet wt.) were homogenized with a Polytron PT10 ( $3 \times 30 \mathrm{~s}$ at half-maximal speed $)$ in solution containing $0.1 \mathrm{M}-\mathrm{KCl}, 20 \mathrm{~mm}$-Tris/maleate buffer (pH 6.8), 5 mM- $\mathrm{MgCl}_{2}, 1 \mathrm{~mm}$-EGTA, 1 mM-dithiothreitol and $1 \mathrm{~mm}$-di-isopropyl fluorophosphate. Tris/ maleate buffer was prepared as described by Sasaguri et al. (1985). The crude homogenate was centrifuged at $500 \mathrm{~g}$ for $5 \mathrm{~min}$, and the resultant supernatant was used as a cell homogenate. The particulate fraction $(100000 \mathrm{~g}$ pellet) was prepared as described by Sasaguri et al. (1985). Protein concentration was determined by the method of Lowry et al. (1951). The homogenate or particulate fraction $(2 \mathrm{mg}$ of protein $/ \mathrm{ml}$ ) was ADPribosylated by incubation in a solution containing $0.1 \mathrm{M}-\mathrm{KCl}, 20 \mathrm{~mm}$-Tris/maleate buffer (pH 6.8), $2 \mathrm{~mm}$ $\mathrm{MgCl}_{2}, 1 \mathrm{~mm}$-ATP, 20 mM-thymidine, $10 \mu \mathrm{M}-\mathrm{NAD}^{+}$ and $100 \mu \mathrm{g}$ of $\mathrm{IAP} / \mathrm{ml}$ for $20 \mathrm{~min}$ at $30^{\circ} \mathrm{C}$. The IAP-treated sample served for measurement of PIP $_{2}$-PDE activity, as described below. In the control sample, IAP was omitted from the incubation medium. When the ADP-ribosylation of proteins during IAP treatment was examined (for Fig. 2), non-radioactive $\mathrm{NAD}^{+}$in the above mixture was replaced by $10 \mu \mathrm{M}$-[adenylate${ }^{32} \mathrm{PJNAD}^{+}$(sp. radioactivity $6.9 \mathrm{Ci} / \mathrm{mmol}$ ). The IAPtreated samples were dissolved in Laemmli (1970) sample buffer containing $1 \%$ SDS and boiled in water for $3 \mathrm{~min}$. The incorporation of ${ }^{32} \mathrm{P}$ into the membrane proteins was determined by separation of the proteins by electrophoresis on an $8 \%$-polyacrylamide gel (Laemmli, 1970), followed by autoradiography for $18 \mathrm{~h}$.

\section{PIP $_{2}$-PDE assay}

Unlabelled PIP $_{2}$ (sodium form; dissolved in water) and [32 P]PIP ${ }_{2}$ (dissolved in chloroform) were prepared as described by Sasaguri et al. (1985). After evaporation of chloroform, [ $\left.{ }^{32} \mathrm{P}\right] \mathrm{PIP}_{2}$ was mixed with unlabelled $\mathrm{PIP}_{2}$ to give a specific radioactivity of 100 c.p.m./nmol and then sonicated to become homogeneous. The control or IAP-treated homogenate of arterial smooth muscle (protein concn. $0.2 \mathrm{mg} / \mathrm{ml}$ ), prepared as described above, was incubated in the assay medium $(1 \mathrm{ml})$ containing $0.1 \mathrm{M}-\mathrm{KCl}, 20 \mathrm{~mm}-\mathrm{Tris} / \mathrm{maleate}$ buffer (pH 6.8), $1 \mathrm{~mm}-$ $\mathrm{MgCl}_{2}, 0.14 \mu \mathrm{M}-\mathrm{Ca}^{2+}\left(0.12 \mathrm{mM}-\mathrm{CaCl}_{2}\right.$ plus $1 \mathrm{~mm}$-EGTA; Sasaguri et al., 1985), $10 \mu \mathrm{M}-\mathrm{GTP}[\mathrm{S}], 100 \mu \mathrm{M}-{ }^{32} \mathrm{P}^{3} \mathrm{PIP}_{2}$ and $10 \mu \mathrm{M}$-eserine, with or without $10 \mu \mathrm{M}$-acetylcholine $(\mathrm{ACh})$, at $37^{\circ} \mathrm{C}$ for indicated times. The reaction was terminated by addition of $1 \mathrm{ml}$ of $10 \%(\mathrm{w} / \mathrm{v})$ trichloroacetic acid. Procedures used for the assay of $\left.{ }^{32} \mathrm{P}\right] \mathrm{IP}_{3}$ production were the same as described by Sasaguri et al. (1985).

\section{Assay of inositol phospholipids and phosphatidic acid}

Muscle strips (about $40 \mathrm{mg}$ wet wt.) prepared as described above were radiolabelled in phosphate-free Krebs-Ringer solution ( $\mathrm{pH} 7.4$ ), containing $40 \mu \mathrm{Ci}$ of $\left.{ }^{32} \mathrm{P}\right] \mathrm{P}_{\mathrm{i}}$ (sp. radioactivity $30-40 \mathrm{Ci} / \mathrm{mmol}$ ) $/ \mathrm{ml}$, at $37^{\circ} \mathrm{C}$ for $2 \mathrm{~h}$, and bubbled with $\mathrm{O}_{2} / \mathrm{CO}_{2}(19: 1)$. IAP $(100 \mathrm{ng} / \mathrm{ml})$ was then added to the medium, and the incubation continued for an additional $3 \mathrm{~h}$. The strips were then washed three times with a solution containing $20 \mathrm{~mm}$ Hepes/Tris buffer ( $\mathrm{pH} 7.4$ ), $130 \mathrm{~mm}-\mathrm{NaCl}, 5 \mathrm{~mm}-\mathrm{KCl}$, $1 \mathrm{~mm}-\mathrm{MgCl}_{2}, 1.5 \mathrm{~mm}-\mathrm{CaCl}_{2}, 1 \mathrm{~mm}-\mathrm{KH}_{2} \mathrm{PO}_{4}$ and $5.5 \mathrm{~mm}-$ glucose, and then stimulated with $10 \mu \mathrm{M}-\mathrm{ACh}$ in $500 \mu \mathrm{l}$ of the solution for various times (10-120 s). Hepes/Tris buffer was made by adjusting approx. $0.2 \mathrm{M}$-Hepes to $\mathrm{pH} 7.4$ at $37^{\circ} \mathrm{C}$ with Tris and diluting to $20 \mathrm{~mm}$. The reaction was halted by adding $1.8 \mathrm{ml}$ of ice-cold chloroform/methanol/12 $\mathrm{M}-\mathrm{HCl}$ (50:100:1, by vol.). The strips were then homogenized with a glass homogenizer. Crude lipid extract in the solvent was chromatographed on a silica gel 60 plate (Merck), as described by Billah \& Lapetina (1982). The plate was then autoradiographed on Sakura X-ray film for $12-15 \mathrm{~h}$. The fractions corresponding to PI, PIP, PIP ${ }_{2}$ and PA on the plate were scraped off, and counted for radioactivity in a liquid-scintillation counter.

\section{Assay of inositol phosphates}

The muscle strip prepared as described above was labelled with $5 \mu \mathrm{Ci}$ of myo-[2- $\left.{ }^{3} \mathrm{H}(\mathrm{n})\right]$ inositol (sp. radioactivity $15.8 \mathrm{Ci} / \mathrm{mmol}) / \mathrm{ml}$ in Krebs-Ringer solution (pH 7.4) at $37^{\circ} \mathrm{C}$ for $6 \mathrm{~h}$, bubbled with $\mathrm{O}_{2} / \mathrm{CO}_{2}(19: 1)$. For the final $3 \mathrm{~h}$, IAP $(100 \mathrm{ng} / \mathrm{ml})$ was added to the medium. After washing three times with solution containing $20 \mathrm{~mm}$-Hepes/Tris buffer (pH 7.4), $120 \mathrm{~mm}-\mathrm{NaCl}, 10 \mathrm{~mm}-\mathrm{LiCl}, 5 \mathrm{~mm}-\mathrm{KCl}, 1 \mathrm{~mm}-\mathrm{MgCl}_{2}$, $1.5 \mathrm{~mm}-\mathrm{CaCl}_{2}, 1 \mathrm{mM}-\mathrm{KH}_{2} \mathrm{PO}_{4}$ and $5.5 \mathrm{~mm}$-glucose, the strip was stimulated with $10 \mu \mathrm{M}$-ACh in $1 \mathrm{ml}$ of the solution for various times $(10-120 \mathrm{~s})$. The reaction was halted by adding $1 \mathrm{ml}$ of $10 \%$ trichloroacetic acid. The tissue was then homogenized, and after centrifugation at $1000 \mathrm{~g}$ for $10 \mathrm{~min}$ the acid-soluble supernatant was treated with diethyl ether $(3 \times 10 \mathrm{ml})$ to remove the trichloroacetic acid. After neutralization with $\mathrm{NaOH}$, the supernatant was applied to a column containing $1 \mathrm{ml}$ of Dowex 1 (formate form; 50-100 mesh) anion-exchange resin, for an analysis of inositol phosphates (Sasaguri et al., 1985).

\section{Cyclic AMP assay}

Muscle strips (about $20 \mathrm{mg}$ wet wt.) were incubated in Krebs-Ringer solution, with or without $100 \mathrm{ng}$ of IAP $/ \mathrm{ml}$, for $3 \mathrm{~h}$. After washing with solution containing $20 \mathrm{~mm}$-Hepes/Tris buffer (pH 7.4), $130 \mathrm{~mm}-\mathrm{NaCl}$, $5 \mathrm{~mm}-\mathrm{KCl}, 1 \mathrm{~mm}-\mathrm{MgCl}_{2}, 1.5 \mathrm{~mm}-\mathrm{CaCl}_{2}, 1 \mathrm{~mm}-\mathrm{KH}_{2} \mathrm{PO}_{4}$ and $5.5 \mathrm{mM}$-glucose, the strip was stimulated with various concentrations of $L$-isoprenaline in $1 \mathrm{ml}$ of the same solution at $37^{\circ} \mathrm{C}$ for $3 \mathrm{~min}$. The reaction was halted by immersing the muscle strip into liquid $\mathrm{N}_{2}$. The concentration of cyclic AMP of the extract was measured with a radioimmunoassay kit (Yamasa Shoyu, Tokyo, Japan).

\section{Recordings of mechanical activity of the muscles}

To record tension of the muscle cells, the vessel was carefully teased apart with jeweller's forceps, opened along the longitudinal direction, and circular cut strips (50-75 $\mu \mathrm{m}$ in width, $300 \mu \mathrm{m}$ in length and $20 \mu \mathrm{m}$ in thickness) were prepared, in Krebs-Ringer solution. The preparation was set up in a small chamber $(0.9 \mathrm{ml})$ through which the test solution was superfused rapidly by jetting from one end and by siphoning off simultaneously with a water pump from the other end. Both ends of the preparation were fixed between pieces of Scotch double stick tape (3 M Co., St Paul, MN, U.S.A.), and isometric tension was recorded with a strain-gauge transducer (U-gauge; Shinko Co., Tokyo, Japan). The tissue was superfused with solution containing $20 \mathrm{~mm}$-Hepes/Tris buffer ( $\mathrm{pH} 7.4), 130 \mathrm{mM}-\mathrm{NaCl}$, $5 \mathrm{~mm}-\mathrm{KCl}, 1 \mathrm{~mm}-\mathrm{MgCl}_{2}, 1.5 \mathrm{~mm}-\mathrm{CaCl}_{2}, 1 \mathrm{~mm}-\mathrm{KH}_{2} \mathrm{PO}_{4}$, 


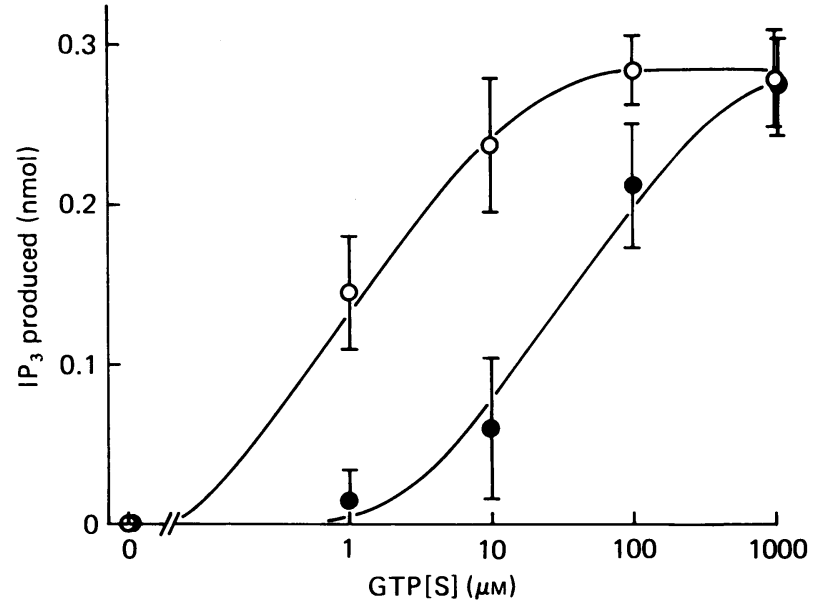

Fig. 1. Effects of various concentrations of GTP[S] on the activity of $\mathrm{PIP}_{2}-\mathrm{PDE}$ for production of $\mathrm{IP}_{3}$ in the particulate fraction

The particulate fraction $(0.5 \mathrm{mg}$ of protein $/ \mathrm{ml})$ was incubated with $\left.{ }^{32} \mathrm{P}\right] \mathrm{PIP}_{2}(100 \mu \mathrm{M})$ in a solution containing $0.1 \mathrm{M}-\mathrm{KCl}, \quad 20 \mathrm{mM}$-Tris $/$ maleate buffer ( $\mathrm{pH} \mathrm{6.8)}$, $1 \mathrm{mM}-\mathrm{MgCl}_{2}, 0.14 \mu \mathrm{M}$ free $\mathrm{Ca}^{2+}$, the indicated concentration of GTP[S], and $10 \mu \mathrm{M}$-eserine: $\mathrm{O}, 10 \mu \mathrm{M}-\mathrm{ACh}$; $\mathrm{C}$, no ACh. Vertical bars indicate S.E.M. $(n=5)$.

$5.5 \mathrm{~mm}$-glucose and various concentrations of IAP, at $32{ }^{\circ} \mathrm{C}$ for $4-12 \mathrm{~h} . \mathrm{CaCl}_{2}$ was omitted and $2 \mathrm{~mm}$-EGTA was added to make the $\mathrm{Ca}^{2+}$-free buffer. The above solution containing $10 \mu \mathrm{M}-\mathrm{ACh}$ was applied to induce contraction. $\mathrm{NaCl}(130 \mathrm{mM})$ was replaced with an equimolar concentration of $\mathrm{KCl}$ to obtain the $\mathrm{K}^{+}$-induced contraction (Itoh et al., 1982).

\section{Chemicals}

IAP was a gift from Professor M. Ui, Hokkaido University, Japan. [adenylate- $\left.{ }^{32} \mathrm{P}\right] \mathrm{NAD}^{+}$and myo-[2-
${ }^{3} \mathrm{H}(\mathrm{n})$ ]inositol were purchased from New England Nuclear. GTP[S] was from Boehringer Mannheim. Other compounds, including $\mathrm{ACh}$, eserine, $\mathrm{NAD}^{+}$, ATP, thymidine, and 1-isoprenaline, were from Sigma.

\section{RESULTS}

Effect of GTP[S] on PIP - -PDE activity in the particulate fraction of the coronary artery

The effects of ACh with GTP[S] on the PIP $_{2}-\mathrm{PDE}$ activity were examined by using the particulate fraction of the coronary artery (Fig. 1). In the presence of $1 \mathrm{mM}-\mathrm{MgCl}_{2}, \mathrm{GTP}[\mathrm{S}]$ in a concentration-dependent manner produced $\mathrm{IP}_{3}$. However, in the presence of $\mathrm{ACh}$, the dose-response curve for GTP[S] activation of the $\mathrm{PIP}_{2}$-PDE was shifted to the left. At concentrations over $100 \mu \mathrm{M}, \mathrm{GTP}[\mathrm{S}]$ alone stimulated the $\mathrm{PIP}_{2}-\mathrm{PDE}$ activity, and at $1 \mathrm{mM}, \mathrm{IP}_{3}$ was produced maximally, irrespective of the presence of $10 \mu \mathrm{M}-\mathrm{ACh}$. These results indicate that guanine nucleotides may regulate $A C h$-induced $\mathrm{PIP}_{2}$ hydrolysis, the effects of which may be exerted through a G-protein located in the plasma membrane. The effect of GTP[S] was also observed with the particulate fraction, as with the homogenate (Sasaguri et al., 1985). However, the activity of $\mathrm{PIP}_{2}-\mathrm{PDE}$ in the particulate fraction was much lower than that in the homogenate, i.e. $1.4 \mathrm{nmol}$ of $\mathrm{IP}_{3}$ was produced by incubating PIP $_{2}$ with $0.5 \mathrm{mg}$ of the homogenate protein for $2 \mathrm{~min}$, whereas only $0.28 \mathrm{nmol}$ was produced with the same concentration of proteins in the particulate fraction. Thus we used the homogenate fraction to examine whether the G-protein involved in the ACh-stimulated $\mathrm{PIP}_{\mathbf{2}}$ hydrolysis in the pig coronary artery is sensitive to IAP.

\section{Effect of IAP-treated homogenates on PIP $_{2}$-PDE} activity in smooth muscles of the coronary artery

Fig. 2(a) shows an autoradiogram of the electrophoretic pattern of the homogenate and particulate fractions (treated with IAP for $20 \mathrm{~min}$ ) on SDS/polyacrylamide
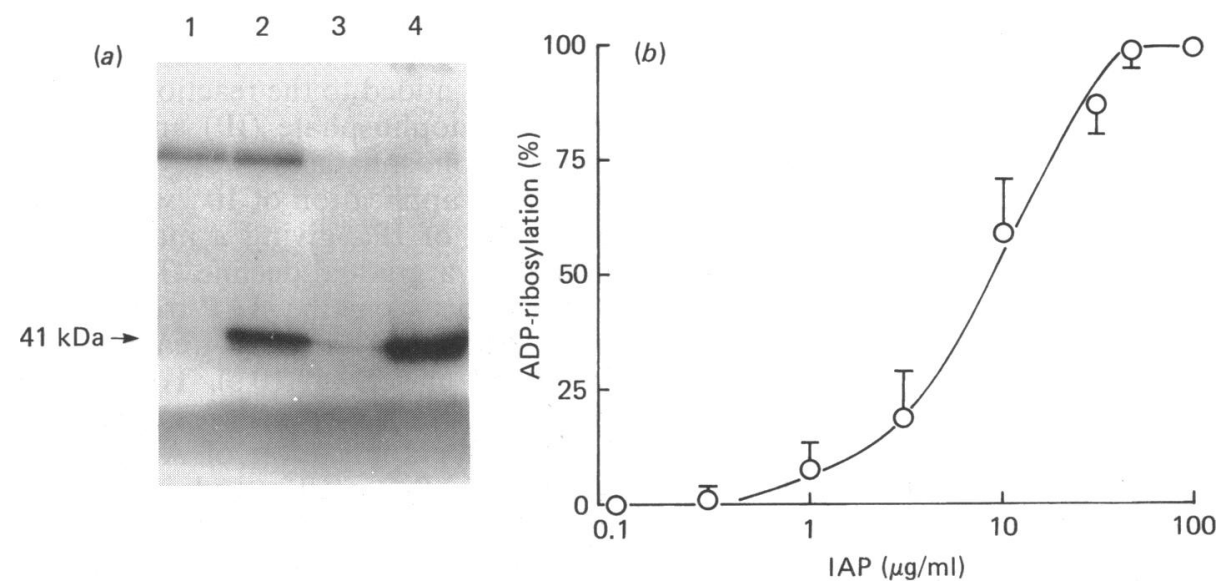

Fig. 2. ADP-ribosylation of the membrane proteins by IAP

The homogenate or the particulate fraction $(2 \mathrm{mg}$ of protein $/ \mathrm{ml})$ was incubated in a medium containing $0.1 \mathrm{M}-\mathrm{KCl}$, $20 \mathrm{~mm}$-Tris/maleate buffer (pH 6.8), $2 \mathrm{mM}-\mathrm{MgCl}_{2}, 1 \mathrm{mM}-\mathrm{ATP}, 20 \mathrm{mM}$-thymidine, $10 \mu \mathrm{M}$-[adenylate- ${ }^{32} \mathrm{P}_{\mathrm{NAND}} \mathrm{NaD}^{+}$, and various concentrations of IAP at $30^{\circ} \mathrm{C}$ for $20 \mathrm{~min}$. (a) Autoradiogram of SDS/polyacrylamide gel. Lanes 1 and 2, homogenate; lanes 3 and 4 , the particulate fraction; lanes 1 and 3 , no IAP; lanes 2 and $4,+100 \mu \mathrm{g}$ of IAP/ml. (b) Dependence on IAP concentration of ADP-ribosylation of $41 \mathrm{kDa}$ protein in the cell homogenate. The radioactivities of $41 \mathrm{kDa}$ protein separated by SDS/polyacrylamide-gel electrophoresis are shown as percentages of the activity obtained in the treatment with $100 \mathrm{ng}$ of IAP/ml. Bars show S.E.M. $(n=3)$. 
gel. The native IAP, but not the A-protomer of IAP (an active ADP-ribosylating enzyme), could catalyse the ADP-ribosylation of the $41 \mathrm{kDa}$ protein of the homogenate (lane 2). The protein ADP-ribosylated by IAP may be the $\alpha$-subunit of $N_{i}$, an inhibitory regulatory protein of adenylate cyclase located in the membrane fraction, because the same protein was also observed in the particulate (lane 4), but not in the cytosol fraction (results not shown). The $41 \mathrm{kDa}$ protein appeared to be maximally ribosylated in the presence of $50-100 \mu \mathrm{g}$ of native IAP/ml (Fig. $2 b$ ).

The activity of the PIP $_{2}-\mathrm{PDE}$ was then examined in the homogenate after treatment with $100 \mu \mathrm{g}$ of IAP $/ \mathrm{ml}$. As shown in Fig. $3(a)$, in the presence of $1 \mathrm{mM}-\mathrm{MgCl}_{2}$, $0.14 \mu \mathrm{M}$ free $\mathrm{Ca}^{2+}$ and when using $10 \mu \mathrm{M}-\mathrm{GTP}[\mathrm{S}]$, there

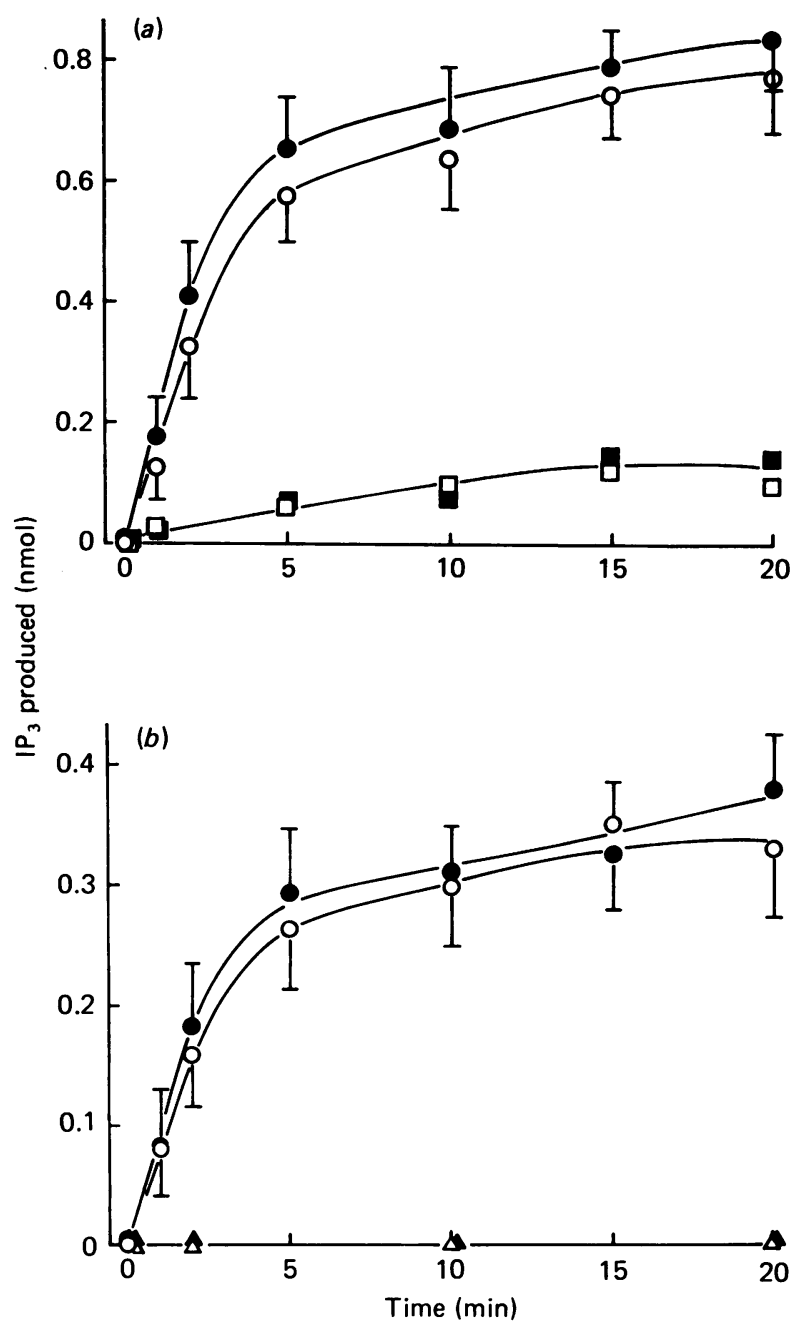

Fig. 3. Effect of IAP treatment of the homogenate on $\mathrm{ACh}$ - or GTP[S]-induced activation of PIP $_{\mathbf{2}}-\mathbf{P D E}$

(a) The homogenate $(0.2 \mathrm{mg} / \mathrm{ml})$ was incubated with [ $\left.{ }^{32} \mathrm{P}\right] \mathrm{PIP}{ }_{2}(100 \mu \mathrm{M})$ in a solution containing $0.1 \mathrm{M}-\mathrm{KCl}$, $20 \mathrm{mM}$-Tris/maleate buffer (pH 6.8), $1 \mathrm{mM}-\mathrm{MgCl}_{2}$, $0.14 \mu \mathrm{M}$ free $\mathrm{Ca}^{2+}, 10 \mu \mathrm{M}$-GTP[S], $10 \mu \mathrm{M}$-eserine, and with $(O, \Theta)$ or without $(\square, \square)$ application of $10 \mu \mathrm{M}$-ACh. $(b)$ The incubation conditions were the same as those in $(a)$, except that the concentration of GTP[S] was $100 \mu \mathrm{M}$ $(O, \Theta)$ or zero $(\triangle, \boldsymbol{\Delta})$, and eserine and $\mathrm{ACh}$ were omitted. $O, \square, \Delta$, Non-treated homogenate; $\boldsymbol{Q}, \boldsymbol{\square}, \Delta$, IAPtreated homogenate. Bars show S.E.M. $(n=5)$. was no apparent production of $\mathrm{IP}_{3}$. However, when $10 \mu \mathrm{M}$-ACh was added, PIP $_{2}$-PDE was activated, leading to $\mathrm{IP}_{3}$ production. The amount of $\mathrm{IP}_{3}$ was seen to increase linearly with time up to $3 \mathrm{~min}$, reaching a plateau at 15-20 min. There was no difference in the $\mathrm{IP}_{3}$ production, activated by $\mathrm{ACh}$, between the IAP-treated and control preparations of the homogenate. Fig. $3(b)$ shows the time course of $\mathrm{IP}_{3}$ production induced by $100 \mu \mathrm{M}-\mathrm{GTP}[\mathrm{S}]$. Again, no difference between the IAP-treated and control samples was observed while measuring GTP[S]-stimulated $\mathrm{IP}_{3}$ production.

These results indicate that a G-protein which is insensitive to ADP-ribosylation catalysed by IAP may be involved in the ACh- or GTP[S]-induced activation of PIP $_{2}$-PDE.

\section{Efiects of IAP treatment of muscle cells on ACh-induced changes in the amount of inositol phospholipids, phosphatidic acid or inositol phosphates}

Our tentative conclusion, that G-protein involved in the ACh-induced PIP $_{2}$ hydrolysis in the coronary artery is not an IAP substrate, was confirmed by examining the amount of inositol phospholipids and of inositol phosphates in the intact muscles stimulated with ACh.

Fig. 4 shows ACh-induced changes in the amount of inositol phospholipids, in both IAP-treated and nontreated smooth muscles of the coronary artery. Application of $10 \mu \mathrm{M}$-ACh decreased the amount of PIP $_{2}$, within $10 \mathrm{~s}$, and similar results were observed on the IAP-treated muscle preparation. For example, at $10 \mathrm{~s}$ after application of $\mathrm{ACh}$, the amount of PIP decreased to $48 \pm 7 \%$ of the control, in non-treated muscle, and to $42 \pm 6 \%$ in IAP-treated muscle. The amount of PIP also decreased within $10 \mathrm{~s}$, in both samples $(63 \pm 8 \%$ in IAP-treated and $58 \pm 7 \%$ in non-treated muscle, at $10 \mathrm{~s})$. The decrease in

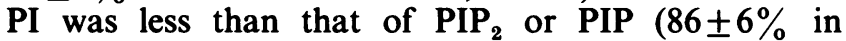
IAP-treated and $88 \pm 6 \%$ in non-treated muscle, at $120 \mathrm{~s})$. The PA content gradually increased and was not affected by IAP treatment $(180 \pm 17 \%$ in IAP-treated and $202 \pm 18 \%$ in non-treated muscle, at $120 \mathrm{~s}$ ). We also observed the effect of IAP treatment on the production of inositol phosphates in the water-soluble fraction of $\left[{ }^{3} \mathrm{H}\right]$ inositol-labelled muscle stimulated with $\mathrm{ACh} . \mathrm{LiCl}$ $(10 \mathrm{~mm})$ was added to the reaction medium to inhibit the inositol monophosphate (IP) and inositol 1,4-bisphosphate (IP ${ }_{2}$ ) phosphatases (Storey et al., 1984). As shown in Fig. 5(a), application of $10 \mu \mathrm{M}$-ACh rapidly increased the amount of $\mathrm{IP}_{3}$, giving a maximal increase at $10 \mathrm{~s}$, followed by a gradual decline. There was no significant difference between the IAP-treated and non-treated muscle $(155 \pm 11 \%$ in IAP-treated and $143 \pm 13 \%$ in non-treated muscle, at $10 \mathrm{~s}$ ). Total inositol phosphate, comprising $\mathrm{IP}_{3}, \mathrm{IP}_{2}$ and IP, was gradually increased up to $120 \mathrm{~s}$ after application of $\mathrm{ACh}$, with no difference between IAP-treated and non-treated muscles $(163 \pm 10 \%$ in IAP-treated and $157 \pm 12 \%$ in non-treated muscle, at $120 \mathrm{~s}$ ) (Fig. $5 b$ ). The gradual decrease in the accumulated $\mathrm{IP}_{3}$ during the prolonged incubation may be due to degradation by $\mathrm{IP}_{3}$ phosphatase, which is not inhibited by $\mathrm{Li}^{+}$(Storey et al., 1984; Sasaguri et al., 1985).

As shown in Table 1, the production of cyclic AMP by isoprenaline was enhanced by the treatment with IAP, with maximum effect being observed at $100 \mathrm{ng}$ of $\mathrm{IAP} / \mathrm{ml}$. The enhancement of $\beta$-adrenergic-stimulated cyclic AMP accumulation, in the IAP-treated muscle, 

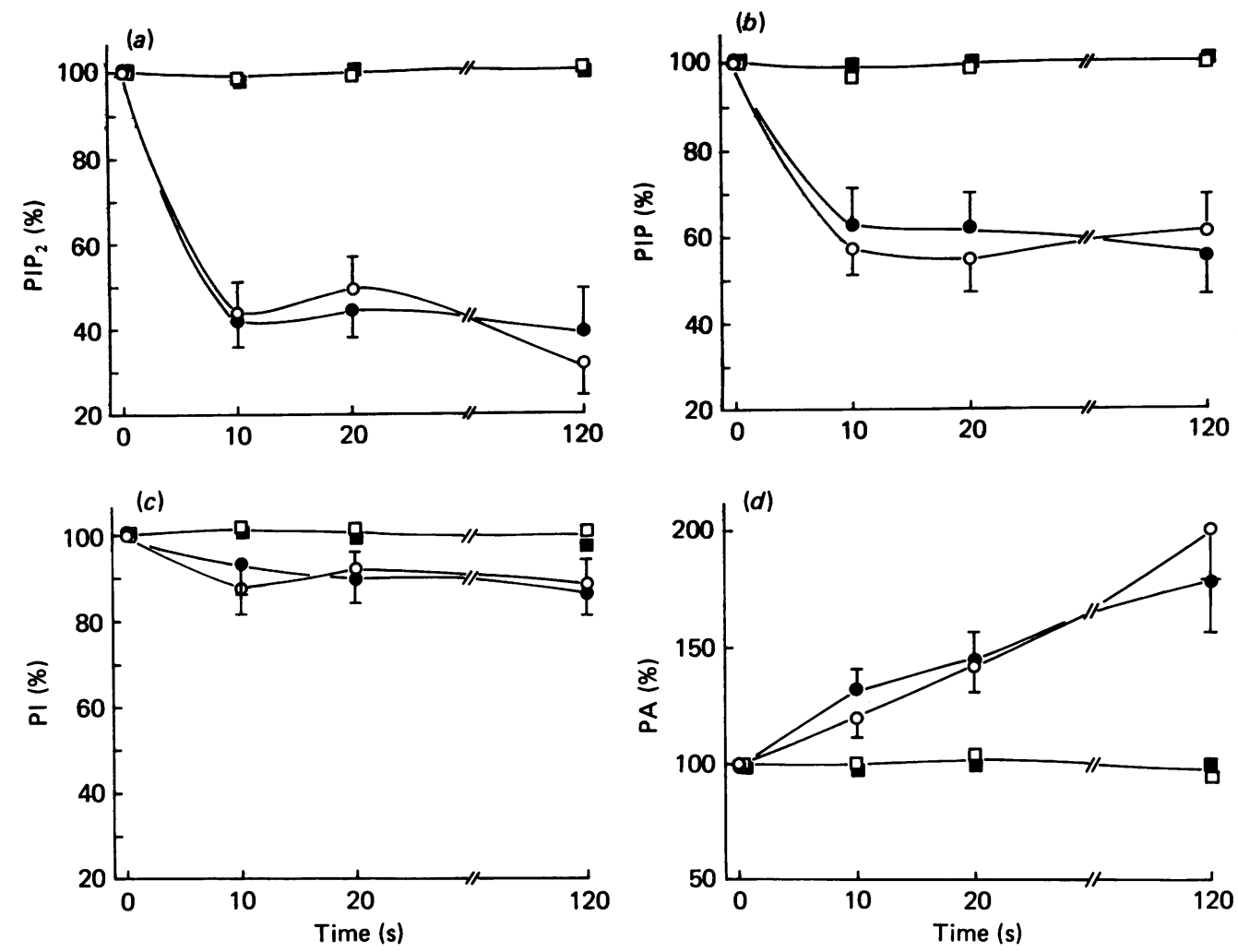

Fig. 4. Efiect of IAP treatment on hydrolysis of inositol phospholipids induced by ACh in intact smooth muscles

${ }^{32} \mathrm{P}$-labelled arterial muscle incubated in the absence $(O, \square)$ or presence $(O, \square)$ of $100 \mu \mathrm{g}$ of IAP/ml for $3 \mathrm{~h}$ was stimulated by $10 \mu \mathrm{M}-\mathrm{ACh}$ at zero time. The amounts of inositol phospholipids and PA were determined by the assay method described in the Materials and methods section. (a) PIP ${ }_{2}$; (b) PIP; (c) PI; (d)PA. O, , $10 \mu \mathrm{M}-\mathrm{ACh}$; $\square$, $\square$, no ACh. The amount of each lipid before the stimulation was normalized as $100 \%$ [non-treated: PIP $_{2}, 65154 \pm 6492 ; \mathrm{PIP}, 10476 \pm 963 ; \mathrm{PI}, 35112 \pm 4221 ; \mathrm{PA}$, $12936 \pm 759$ (c.p.m./mg of protein); IAP-treated: PIP ${ }_{2}, 49554 \pm 4003$; PIP, $8160 \pm 824$, PI, $34092 \pm 4107$; PA, $11208 \pm 823$ (c.p.m./mg of protein)]. Vertical bars indicate S.E.M. $(n=5)$.

may reflect elimination of the functioning of $\mathrm{N}_{i}$ by IAP treatment. Incubation of intact muscles for $3 \mathrm{~h}$ with IAP seemed adequate to eliminate the physiological functions of $\mathrm{N}_{\mathrm{i}}$. The application of $10 \mu \mathrm{M}-\mathrm{ACh}$ for $3 \mathrm{~min}$ did not alter the cellular cyclic AMP content in both IAP-treated and non-treated muscles $(4.9 \pm 0.4$ in non-treated and $4.8 \pm 0.6 \mathrm{pmol} / \mathrm{mg}$ of protein in IAP-treated muscle).

\section{Effect of IAP treatment on the mechanical responses induced by $\mathrm{ACh}$}

Fig. 6(a) shows the mechanical responses in control and IAP-treated muscle, as induced by either high $\mathrm{K}^{+}$or $\mathrm{ACh}$, with or without external $\mathrm{Ca}^{2+}$. High- $\mathrm{K}^{+}(135 \mathrm{mM})-$ induced contraction was completely blocked by the addition of $0.1 \mu \mathrm{M}$-nifedipine, a potent $\mathrm{Ca}^{2+}$-channel blocker, and was not observed in the absence of external $\mathrm{Ca}^{2+}$ (results not shown), thereby indicating that this contraction is caused by a voltage-dependent $\mathrm{Ca}^{2+}$ influx (Kuriyama et al. 1982). On the other hand, the contraction evoked by $10 \mu \mathrm{M}$-ACh was much larger than that induced by high $\mathrm{K}^{+}$(compare A-2 with A-1 in Fig. 6) and was only slightly decreased in the absence of external $\mathrm{Ca}^{2+}$ (compare A-3 with A-2). The contraction evoked by $\mathrm{ACh}$ in the absence of $\mathrm{Ca}^{2+}$ showed characteristics of the shortening of duration of tension rather than a decrease in the maximal amplitude. Since the application of ACh to this tissue modified neither the membrane potential nor the membrane resistance (Ito et al., 1979) and the ACh-induced contraction was not inhibited by $\mathrm{Ca}^{2+}$-channel blockers (Itoh et al., 1984), the contraction induced by $\mathrm{ACh}$ is probably mainly due to mobilization of stored $\mathrm{Ca}^{2+}$. The receptor-operated $\mathrm{Ca}^{2+}$ influx may also contribute to the continuation of the tension in the presence of external $\mathrm{Ca}^{2+}$ (Itoh et al., 1984).

When the muscle strips were preincubated with IAP in concentrations over $30 \mathrm{ng} / \mathrm{ml}$ at $35^{\circ} \mathrm{C}$ for $3 \mathrm{~h}$, the ACh-induced contraction was slightly inhibited (see B-2, B-3, C-2 and C-3, Fig. 6), but the high- $\mathrm{K}^{+}$-induced contraction was not affected (see B-1 and C-1). Fig. 6(b) shows a plot of the maximal tension in muscles treated with various doses of IAP, relative to that in the control (non-treated) sample. The ACh-induced tension was decreased to 78 or $68 \%$ in muscle treated with $100 \mathrm{ng}$ of IAP $/ \mathrm{ml}$ and 92 or $86 \%$ in muscle treated with $30 \mathrm{ng}$ of IAP $/ \mathrm{ml}$ in the presence or absence of external $\mathbf{C a}^{2+}$ respectively.

\section{DISCUSSION}

In the present study using the homogenate or particulate fraction of the pig coronary artery, native IAP catalysed the ADP-ribosylation of $41 \mathrm{kDa}$ protein, even in the absence of a preactivated A-protomer. Similar observations were made with C6 glioma cells by Tamura et al. (1982) and Katada et al. (1983). These may 

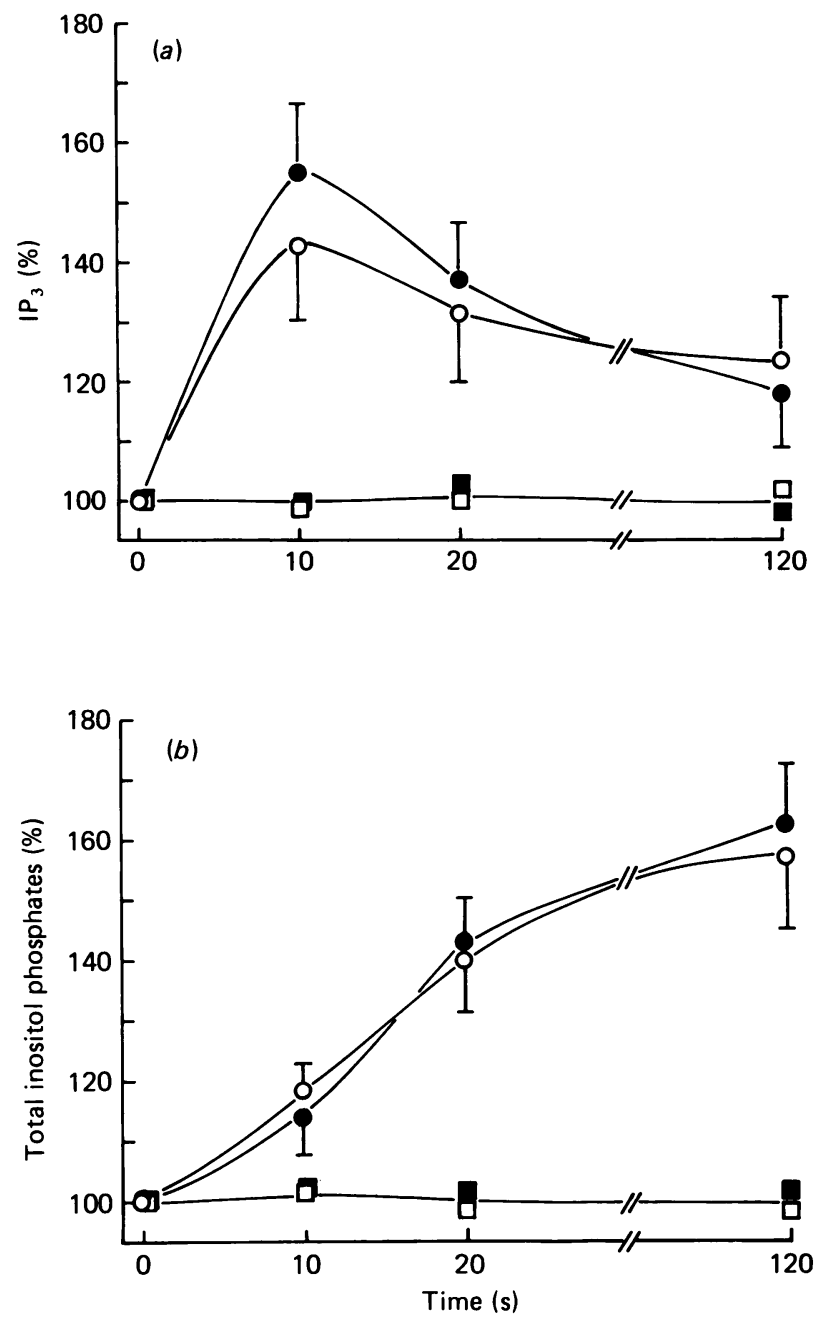

Fig. 5. Effects of IAP treatment on accumulation of inositol phosphates induced by ACh in intact smooth muscles

$\left[{ }^{3} \mathrm{H}\right]$ Inositol-labelled arterial muscle, not treated $(\mathrm{O}, \square)$ or treated with $100 \mathrm{ng}$ of $\mathrm{IAP} / \mathrm{ml}$ for $3 \mathrm{~h}(O, \square)$ was stimulated by $10 \mu \mathrm{M}-\mathrm{ACh}$ at zero time, in the presence of $10 \mathrm{~mm}-\mathrm{LiCl}$. The assay method for inositol phosphates in the water-soluble fraction was described in the Materials and methods section. (a) $\mathrm{IP}_{3} ;(b)$ total inositol phosphates, including $\mathrm{IP}_{3}, \mathrm{IP}_{2}$ and IP. $\bigcirc, 0,10 \mu \mathrm{M}-\mathrm{ACh} ; \square, \square$, no $\mathrm{ACh}$. The amounts of these inositol phosphates before stimulation by ACh were normalized as $100 \%$ [non-treated: $\mathrm{IP}_{3}, 39.5 \pm 3.1$; total inositol phosphates, $231.5 \pm 32.2$ (c.p.m./mg of protein); IAP-treated: $\mathrm{IP}_{3}, 50.5 \pm 4.7$; total inositol phosphates, $301.0 \pm 26.9$ (c.p.m./mg of protein)]. Bars indicate S.E.M. $(n=5)$.

be due to the close association of the processing enzymes which activate the A-protomer with the particulate fraction.

In the homogenate from coronary artery, although the $41 \mathrm{kDa}$ protein (probably $\alpha$-subunit of $\mathrm{N}_{\mathrm{i}}$ ) was maximally ADP-ribosylated by preincubation with IAP, IP $_{3}$ was produced to the same extent as observed in the control sample from exogenously added $\mathrm{PIP}_{2}$ on addition of ACh and a relatively low dose of GTP[S] $(10 \mu \mathrm{M})$. A relatively high dose $(100 \mu \mathrm{M})$ of GTP[S] itself (without addition of $\mathrm{ACh}$ ) led to the production of $\mathrm{IP}_{3}$, with no difference between IAP-treated or non-treated homo-
Table 1. Enhancement of the accumulation of cyclic AMP stimulated by isoprenaline after treatment with IAP

Cyclic AMP contents in non-treated or IAP-treated muscles were measured $3 \mathrm{~min}$ after stimulation by isoprenaline. The procedure is described in the Materials and methods section. Results are means \pm S.E.M. $(n=5)$.

\begin{tabular}{lrr}
\hline & \multicolumn{2}{c}{ Cyclic AMP (pmol/mg of protein) } \\
\cline { 2 - 3 } & \multicolumn{1}{c}{ Non-treated } & IAP-treated \\
\hline Basal & $4.8 \pm 0.5$ & $4.6 \pm 0.7$ \\
$0.1 \mu \mathrm{M}$-Isoprenaline & $8.5 \pm 0.6$ & $9.6 \pm 0.7$ \\
$1 \mu \mathrm{M}$-Isoprenaline & $10.6 \pm 1.3$ & $16.6 \pm 1.6$ \\
$10 \mu \mathrm{M}$-Isoprenaline & $13.7 \pm 1.6$ & $23.0 \pm 1.7$ \\
\hline
\end{tabular}

genates being observed. The lack of effect of ADP-ribosylation of $\mathrm{N}_{1}$ by IAP treatment on PIP $_{2}$-PDE activity in the cell-free system was confirmed with intact muscle tissues. Enhancement of $\beta$-agonist-stimulated cyclic AMP accumulation by IAP treatment would (albeit indirectly) indicate that $\mathbf{N}_{\mathrm{i}}$ was ADP-ribosylated, and consequently that the function of $\mathrm{N}_{\mathrm{i}}$ was abolished during the pretreatment of intact muscles with IAP, although no appreciable change in cyclic AMP concentrations was observed in unstimulated IAP-treated muscles, as was the case in C6 glioma cells (Katada et al., 1982). The decrease in $\mathrm{PIP}_{2}$ or the production of $\mathrm{IP}_{3}$ observed in $\left[{ }^{32} \mathrm{P}\right]-$ or $\left[{ }^{3} \mathrm{H}\right]$-inositol-labelled muscle stimulated with ACh, respectively, was not affected by prior incubation with IAP. Why the ${ }^{32} \mathrm{P}$ radioactivities of $\mathrm{PIP}_{2}$ and PIP were diminished by approx. $20 \%$ after IAP treatment (see the legend of Fig. 4) is unknown. However, IAP may inhibit PI and PIP kinase, because the ${ }^{32} \mathrm{P}$ radioactivity of PI was not altered by IAP treatment. These results, taken together with those obtained with the cell-free system, strongly suggest that a G-protein, which is insensitive to IAP, is involved in the muscarinic stimulation of $\mathrm{PIP}_{2}$ breakdown in arterial smooth muscles.

Data are accumulating to indicate that $\mathrm{N}_{\mathrm{i}}$ is not the G-protein that mediates inositol phospholipid hydrolysis in at least the majority of cell types. Masters et al. (1985) reported that muscarinic-stimulation-induced $\mathbf{P I P}_{2}$ breakdown and $\mathrm{Ca}^{2+}$ mobilization in cultured chick heart cells and $1321 \mathrm{~N} 1$ human astrocytoma cells was not inhibited by IAP treatment, although the muscarinic inhibition of $\beta$-adrenergic-agonist-induced cyclic AMP accumulation was attenuated by IAP treatment. Martin et al. (1985) obtained confirming evidence that a Gprotein other than $\mathbf{N}_{\mathrm{i}}$ was responsible for muscarinic stimulation in $1321 \mathrm{~N} 1$ cells, i.e. the treatment of membrane preparations with $N$-ethylmaleimide, which inactivated $\mathrm{N}_{\mathrm{i}}$ by alkylation, did not affect the extent of guanine nucleotide-sensitive high-affinity binding of carbachol to muscarinic receptors. Furthermore, Murayama \& Ui (1985) reported that the release of inositol from mouse $3 \mathrm{~T} 3$ fibroblasts, stimulated by thrombin, bradykinin, platelet-activating factor or PA, was not inhibited by prior incubation with IAP, whereas the $\mathrm{Ca}^{2+}$ influx and resulting arachidonate release were markedly inhibited. Moreover, the prostaglandin-induced breakdown of PI was not susceptible to IAP in NG 108-15 cells (Kurose \& Ui, 1985), and bradykinin-stimulated GTPase 
(a)

A (control)

A-1 $135 \mathrm{~mm}-\mathrm{K}^{+} \quad$ A-2 $10 \mu \mathrm{M}-\mathrm{ACh} \quad$ A-3 $10 \mu \mathrm{M}-\mathrm{ACh}$ (Ca-free)

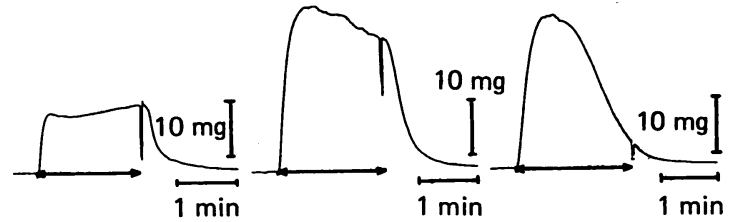

$B(30 \mathrm{ng}$ of $|\mathrm{AP} / \mathrm{m}|)$

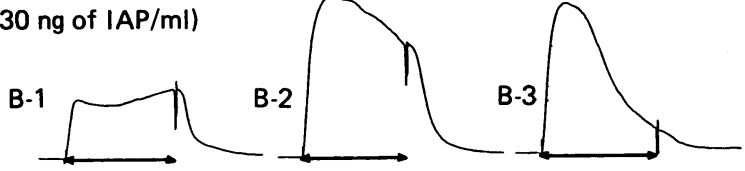

C (100 $\mathrm{ng}$ of $\mid \mathrm{AP} / \mathrm{ml})$

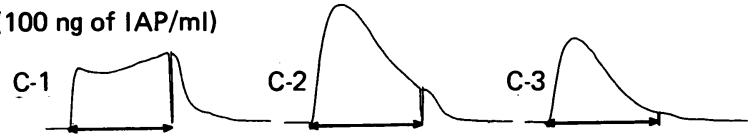

(b)

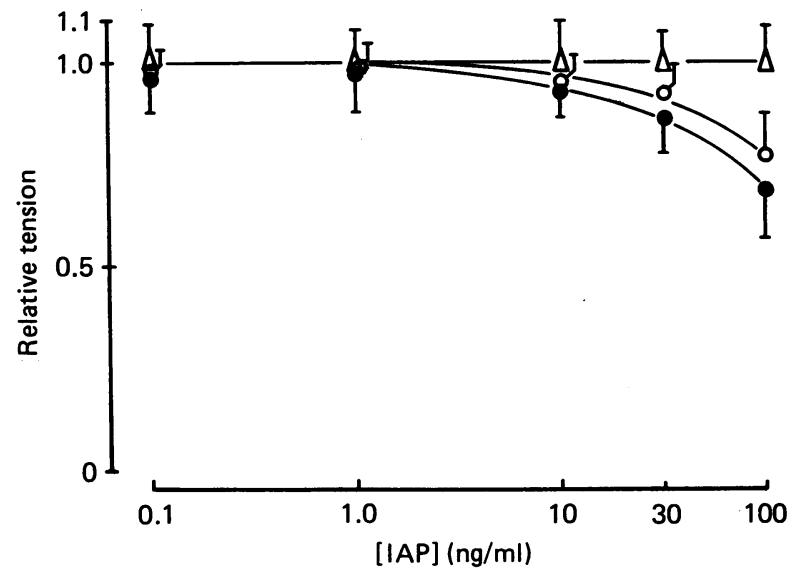

Fig. 6. Effects of IAP treatment on the $K^{+}$-induced and ACh-induced contractions evoked in arterial smooth muscles

(a) Contractions recorded from non-treated muscles (A), or from muscles treated with $30 \mathrm{ng}$ of IAP/ml (B), or $100 \mathrm{ng}$ of IAP $/ \mathrm{ml}$ treated $(\mathrm{C})$, induced by $135 \mathrm{~mm}-\mathrm{K}^{+}(\mathrm{A}-1$, $\mathrm{B}-1, \mathrm{C}-1)$, or by $10 \mu \mathrm{M}-\mathrm{ACh}$ in the presence (A-2, B-2, C-2) or the absence (A-3, B-3, C-3) of external $\mathrm{Ca}^{2+}$. (b) Effects of various concentrations of IAP on the maximum amplitude of contractions evoked by $135 \mathrm{~mm}-\mathrm{K}^{+}(\triangle)$, or by $10 \mu \mathrm{M}-\mathrm{ACh}$ in the presence $(\mathrm{O})$ or the absence $(\mathrm{O})$ of external $\mathrm{Ca}^{2+}$. Relative amplitudes of the contraction evoked by high $\mathrm{K}^{+}$or $\mathrm{ACh}$ in the non-treated muscles were normalized as 1.0. Bars indicate S.E.M. $(n=5)$.

activity in the membrane preparation of NG 108-15 cells was not eliminated by prior incubation with IAP, although the muscarinic receptor may be coupled with $\mathbf{N}_{\mathrm{i}}$ (Grandt et al., 1986). Houslay et al. (1986) reported that platelet-activating factor and U44069, which stimulate inositol phospholipid metabolism in human platelets, activate a GTPase which is distinct from $\mathbf{N}_{\mathbf{s}}$ (a stimulatory G-protein of the adenylate cyclase system; Ui, 1984) and $N_{i}$, using cholera toxin and IAP respectively. Therefore whether or not G-protein involved in signal transduction by $\mathrm{Ca}^{2+}$-mobilizing agonists is an IAP substrate seems to differ with the tissue and agonists. Further studies are required to identify the G-protein.

The mechanical responses in muscles are reflections of the changes in the myoplasmic free $\mathrm{Ca}^{2+}$ concentration (Kuriyama et al., 1982). The increase in the myoplasmic free $\left[\mathrm{Ca}^{2+}\right]$, as induced by $\mathrm{ACh}$ in the presence of external $\mathrm{Ca}^{2+}$, is mainly due to mobilization from $\mathrm{Ca}^{2+}$ stores. The receptor-operated $\mathrm{Ca}^{2+}$ influx may also contribute, but to a lesser extent, as the ACh-induced contraction was slightly larger and continued longer than was observed in the absence of $\mathrm{Ca}^{2+}$ in the solution. The treatment of muscle with IAP may not modify the mechanical machinery, since the high- $\mathrm{K}^{+}$-induced contraction was not altered by IAP treatment. However, the ACh-induced contraction was moderately inhibited by IAP treatment, with or without external $\mathrm{Ca}^{2+}$, thereby indicating that the myoplasmic $\mathrm{Ca}^{2+}$-increasing process is inhibited. It seems possible that the receptor-operated $\mathrm{Ca}^{2+}$ channel is closely associated with the IAP substrate $N_{i}$, because the continuation of the ACh-induced contraction in the presence of external $\mathrm{Ca}^{2+}$ was abolished in IAP-treated muscles. Such may be the case in neutrophils. The IAP treatment of neutrophils completely eliminated the chemotactic-peptide-stimulated $\mathrm{Ca}^{2+}$ influx (Okajima \& Ui, 1984), probably caused by the opening of receptoroperated $\mathrm{Ca}^{2+}$ channels (Reuter, 1983). Another explanation for mechanisms underlying decreases in the contraction may be involvement of accumulation of cyclic AMP by IAP treatment, because cyclic AMP will inhibit the contraction (Itoh et al., 1985). However, the cellular content of cyclic AMP remained unchanged in the IAP-treated muscle, in the absence or presence of ACh. Further experiments on the mechanism underlying the inhibitory action of IAP on the agonist-induced contraction are required.

This work was supported by a Grant-in-Aid for Scientific Research from the Ministry of Education, Science and Culture of Japan. We thank M. Ohara for reading the manuscript.

\section{REFERENCES}

Berridge, M. J. \& Irvine, R. F. (1984) Nature (London) 312, 315-321

Billah, M. M. \& Lapetina, E. G. (1982) J. Biol. Chem. 257, 12705-12708

Cockcroft, S. \& Gomperts, B. D. (1985) Nature (London) 314, 534-536

Gomperts, B. D. (1983) Nature (London) 306, 64-66

Grandt, R., Greiner, C., Zubin, P. \& Jakobs, K. H. (1986) FEBS Lett. 196, 279-283

Haslam, R. J. \& Davidson, M. M. L. (1984) FEBS Lett. 174, 90-95

Houslay, M. D., Bojanic, D. \& Wilson, A. (1986) Biochem. J. 234, 737-740

Ito, Y., Kitamura, K. \& Kuriyama, H. (1979) J. Physiol. (London) 294, 595-611

Itoh, T., Kajiwara, M., Kitamura, K. \& Kuriyama, H. (1982) J. Physiol. (London) 322, 107-125

Itoh, T., Kanmura, Y., Kuriyama, H. \& Suzuki, H. (1984) Br. J. Pharmacol. 83, 243-258

Itoh, T., Kanmura, Y., Kuriyama, H. \& Sasaguri, T. (1985) Br. J. Pharmacol. 84, 393-406

Katada, T., Amano, T. \& Ui, M. (1982) J. Biol. Chem. 257, 3739-3746

Katada, T., Tamura, M. \& Ui, M. (1983) Arch. Biochem. Biophys. 224, 290-298 
Kuriyama, H., Ito, Y., Suzuki, H., Kitamura, K. \& Itoh, T. (1982) Am. J. Physiol. 243, H641-H662

Kurose, H. \& Ui, M. (1985) Arch. Biochem. Biophys. 238, 424-434

Laemmli, U. K. (1970) Nature (London) 227, 680-685

Litosch, I., Wallis, C. \& Fain, J. N. (1985) J. Biol. Chem. 260, 5464-5471

Lowry, O. H., Rosebrough, N. J., Farr, A. L. \& Randall, R. J. (1951) J. Biol. Chem. 193, 265-275

Martin, M. W., Evans, T. \& Harden, T. K. (1985) Biochem. J. 229, 539-544

Masters, S. B., Martin, M. W., Harden, T. K. \& Brown, J. H. (1985) Biochem. J. 227, 933-937

Murayama, T. \& Ui, M. (1985) J. Biol. Chem. 260, 7226-7233

Nakamura, T. \& Ui, M. (1985) J. Biol. Chem. 260, 3584-3593

Nishizuka, Y. (1984) Nature (London) 308, 693-698

Received 28 April 1986/16 June 1986; accepted 1 July 1986
Okajima, F. \& Ui, M. (1984) J. Biol. Chem. 259, 13863-13871

Okajima, F., Katada, T. \& Ui, M. (1985) J. Biol. Chem. 260, 6761-6768

Reuter, H. (1983) Nature (London) 301, 569-574

Sasaguri, T., Hirata, M. \& Kuriyama, H. (1985) Biochem. J. 231, 497-503

Smith, C. D., Lane, B. C., Kusaka, I., Verghese, M. W. \& Snyderman, R. (1985) J. Biol. Chem. 260, 5875-5878

Storey, D. J., Shears, S. B., Kirk, C. J. \& Michell, R. H. (1984) Nature (London) 312, 374-376

Tamura, M., Nogimori, K., Murai, S., Yajima, M., Ito, K., Katada, T., Ui, M. \& Ishii, S. (1982) Biochemistry 21, $5516-5522$

Ui, M. (1984) Trends Pharmacol. Sci. 5, 277

Wallace, M. A. \& Fain, J. N. (1985) J. Biol. Chem. 260, 9527-9530 